\title{
DIETARY HABIT AND NUTRITIONAL STATUS OF INDIGENOUS TRIBAL POPULATION OF WEST DISTRICT OF TRIPURA- A CROSS-SECTIONAL STUDY
}

\author{
Shyamal Roy1, Taranga Reang², Aman Kumar ${ }^{3}$
}

${ }^{1}$ Associate Professor, Department of Medicine, Agartala Government Medical College and Govinda Ballabh Pant Hospital, Agartala, Tripura.

${ }^{2}$ Assistant Professor, Department of Community Medicine, Agartala Government Medical College and Govinda Ballabh Pant Hospital, Agartala, Tripura.

3Final Year Postgraduate Trainee, Department of Community Medicine, Agartala Government Medical College and Govinda Ballabh Pant Hospital, Agartala, Tripura.

ABSTRACT

\section{BACKGROUND}

The traditional food items still form a significant part of daily food intake of the indigenous people here. Some of the mentionable delicacies of these groups of people are dishes like fermented bamboo shoots, fermented elephant yam (Amorphophallus spp.), fermented fruits and vegetables, beverages, dried food items and fermented fish like locally called "shidal", etc. Objective- To assess the pattern of dietary intake and nutritional status of indigenous population.

\section{MATERIALS AND METHODS}

A cross-sectional study was conducted among 120 individuals regarding dietary habit and assessed their nutritional status. Multistage random sampling technique was applied for selection of study subjects.

\section{RESULTS}

Majority among respondents were female, non-vegetarians, agricultural workers, monthly income of Rs. 10,000/- (approx.) and belonged to nuclear family. The common staple food was rice and other food items preferred were naturally grown forest vegetables like bamboo shoots, banana stem, banana flowers, etc. The dry fermented fish was most commonly preferred in preparation of curry and a special dish Godak. The Godak was a common every day menu prepared by almost all families. The other food items viz. dried or smoked meat, fish or vegetables were also used although not common nowadays due to high cost of the items. Majority of the respondents' weights were within normal range. $74.1 \%$ subjects without abdominal obesity were within normal BMI compared to abdominal obesity (51.4\%) ( $\mathrm{p}=0.002)$. Further, 78.7\% percent subjects who did not consume junk food were within normal BMI compared to junk food eaters $(\mathrm{p}=0.019)$. Majority of the participants were heavy workers and this might be one among many beneficial factors in keeping normal body weight.

\section{CONCLUSION}

Though the results showed dietary habits and physical work were favourable for keeping normal body weight, it cannot be generalised due to a small study. Hence, we recommend analytical studies involving larger population covering wider areas.

\section{KEYWORDS}

Diet, Nutritional Status, Naturally Grown Forest Vegetabl es, Physical Activities, Indigenous Population.

HOW TO CITE THIS ARTICLE:Roy S, Reang T, Kumar A. Dietary habit and nutritional status of indigenous tribal population of west district of Tripura- A cross-sectional study. J. Evolution Med. Dent. Sci. 2017;6(90):6343-6347, DOI: 10.14260/jemds/2017/1380

\section{BACKGROUND}

The tribals are hunters, forestland cultivators and minor forest product collectors, living in isolation near to nature, hence called "Sons of the soil".(1) There are a number of tribes in India, spread over different parts at different levels of socioeconomic development. The term 'tribe' is d erived from the Latin word 'tribus'. Earlier Romans used this term to designate the divisions in society. The present popular

'Financial or Other Competing Interest': None.

Submission 26-09-2017, Peer Review 28-10-2017,

Acceptance 03-11-2017, Published 20-11-2017.

Corresponding Author:

Dr. Taranga Reang,

Assistant Professor,

Department of Community Medicine,

Agartala Government Medical College,

P. O. Kunjaban, Agartala-799006.

E-mail:tarangareang@gmail.com

DOI: $10.14260 /$ jemds $/ 2017 / 1380$

\section{(c) (i) $\odot$}

meaning of 'Tribe' in India refers to a category of people included in the list of Scheduled Tribes.(2) According to Article
342 of the Indian Constitution, the Scheduled Tribes are the tribes or tribal communities or part of or groups within these tribes and tribal communities which have been declared as such by the President through a public notification.(3) Tribal groups constitute $8.61 \%$ of the total population of the country, numbering 104.28 million (2011 census) and covers about $15 \%$ of the country's area. Out of a total of 427 tribal communities in India, more than 130 major tribal communities live in North East India.(3) Tripura the third smallest state in Northeast India is inhabited by about 36 , 73,917 people with a population density of $350 / \mathrm{km}^{2}$ of whom $11,66,813$ belong to the tribal community as reported in the census 2011. Among these the largest tribal group being the Kokborok-speaking tribe of the Tripuri, representing $54.7 \%$ of the Scheduled tribe population of the state followed by the Reang (16.6\% of tribal population) and the rest being Jamatia, Chakma, Halam, Mog, Munda, Kuki, Gar, Naotia, Uchoi, etc.(4) The overwhelming majority of the tribal people (97.4\%) reside in rural areas. The district wise distribution of STs is - West Tripura 39\%, Dhalai 16.7\%, South Tripura 29.1\% and North 
Tripura 15.1\% respectively (according to 2011 census).(5) Quantitative data on nutrition and food intake are hard to find. According to a survey conducted by the Government of India 1998, the intake of cereals and millets, pulses and legumes, leafy vegetables, roots and tubers, and other vegetables by the people was inadequate. Study showed that among tribal households, the intake of cereals and millets, leafy vegetables and other vegetables was above the recommended daily allowance. There were deficiencies in the intake of pulses and legumes, milk and milk products, fats and oil, sugar and jaggery in the tribal villages. Calculations based on intake of nutrients indicate that a higher percentage of tribal families were deficient in energy intake than non-tribal families.(6) The science of human nutrition is mainly concerned with defining the nutritional requirements for the promotion, protection and maintenance of health in all groups of the population. Such knowledge is necessary in order to assess the nutritional adequacy of diets for growth and for maintenance of health in adults of both sexes and during pregnancy and lactation in women.(7) A variety of terms have been used to define the amount of nutrients needed by the body. Of these terms, "Recommended dietary intake or allowance" (RDA) has been widely accepted. RDA is defined as the average daily dietary nutrient intake level sufficient to meet the nutrient requirement of nearly all (97-98\%) healthy individuals in a particular life stage and gender group.(8) Age, gender and body weight largely determine the nutritional requirement of an individual. The nutritional status of an individual is often the result of many interrelated factors. It is influenced by the adequacy of food intake both in terms of quantity and quality and also by the physical health of the individual Diet is defined as the kinds of food on which a person or group lives. A balanced diet is defined as one which contains a variety of foods in such quantities and proportion that the need for energy, amino acids, vitamins, minerals, fats, carbohydrate and other nutrients is ad equately met for maintaining health, vitality and general well-being and also makes a small provision for extra nutrients to withstand short duration of leanness. ${ }^{(9)}$ Like the most of the states of the country, the staple diet of the tribal people consists of common food items like rice, wheat, maize, vegetables, pulses, legumes, egg, meat, pork, fish, crabs, etc. But the traditional food items are still forming a significant part of daily food intake of the indigenous people here. Some of the mentionable delicacies of the tribes include e dishes like- fermented bamboo shoot products; fermented elephant yam (Amorphophallus spp.), fermented fruits and vegetables, beverages, dried food items and fermented fish products like "shidal", "Godak", etc.(9) In present day context, the Indigenous Tribal people of Tripura are far advanced socially and economically compared to fifty years back in the state but still they did not change the dietary habits and maintaining the similar dietary pattern till date. This study aims to assess the food habits and nutritional status of the Indigenous Tribal population of Tripura in present situation. This study may highlight the importance of dietary habits and nutritional status of the indigenous people of the state. le

\section{MATERIALS AND METHODS}

A cross-sectional study was conducted in a rural community of Mohanpur Block during March to April 2016 among 120 Indigenous tribal population of West District of Tripura. West district is divided into subdivisions viz. Mohanpur, Jirania and Sadar sub-divisions (Agartala). Among these, Jirania and Mohanpur are located in rural area. The Mohanpur block area head quarter was approx. $24 \mathrm{~km}$ away from Agartala city. There were approx. 1,93,274 individuals among which 32,533 were tribals in Mohanpur block as per 2011 census. The majority of the population living in the rural villages were indigenous tribal whereas Bengali speaking populations live in the town. The Kokborok speaking Indigenous tribes' viz. Debbarma, Koloi, Jamatias were populated in these areas. Their food habits were almost similar. Topographically, majority of the land areas were plain and persons living in this area depend on cultivation. We used Weight machine, Stethoscope, Measuring tape, Interview schedule, etc for data collection. Pregnant woman, sick persons, under prolonged medication and persons below 18 years were excluded from the study. We used multistage random sampling technique for selection of study area. Again, in this block there were many Gram panchayats. In each gram panchayat, there were many villages or paras or mahallas. We enquired the gram panchayat list from block office and made a list of many paras and out of that the village viz. Sipahi Para, Shankar Senapati Para were selected by simple random technique (lottery method). Data were collected from these two villages. Data were collected from one individual in each house through house to house visit. A predesigned, pretested semi-structured interview schedule was used for data collection which narrates about the dietary habits and the pattern of food intake of the indigenous tribal population. Besides the oral questionnaire method, the subjects were assessed for height, weight, waist and hip circumference. Individual data collections were kept anonymous and strict confidentiality was maintained. At the end of data collection, we entered it in computer in Microsoft excel after preparing master chart in Computer. We calculated percentage; mean (SD), ' $t$ ' test and $\mathrm{X}^{2}$ test were performed as appropriate. Permission was obtained from the IEC.

\section{RESULTS}

There were 120 numbers of subjects interviewed and anthropometric measurements were taken during data collection period from the Sipahi para and Shankar Senapati para under Mohanpur Block. We contacted 126 households, but 2 families refused to provide information, 3 houses locked, and no person over 18 years of age was available in one family during our visit. Nearly sixty two percent respondents were female suggesting females were available at home most of the times. The overall mean $( \pm S D)$ age was $37.20( \pm 14.032)$ years and age ranges from 18 to 80 years. The mean $( \pm S D)$ age for male and female was $38.04( \pm 13.844)$ and $36.68( \pm 14.217)$ years respectively. Forty three percent of the respondents were studied up to matric and above. Seventy five percent were agricultural workers. More than $2 / 3^{\text {rd }}$ of the participants had monthly income of Rs. 10,000/- or below. Majority were nuclear families having 4-6 family members on average and non-vegetarians. Majority (58.33\%) among the subjects were heavy workers (Table 1). It was observed that all of the participants were rice eaters $(100.0 \%)$. Wheat, maize, etc were hardly used as staple food by this group of population. Majority $(87.5 \%)$ had a meal thrice per day and $91.7 \%$ \& $75.8 \%$ participants had the habits of taking breakfast and afternoon tea respectively. Tea and snacks were consumed more frequently as breakfast $(73.6 \%)$ or afternoon tea 
$(60.4 \%)$ respectively. Nearly twenty five percent $(24.5 \%)$ and $39.6 \%$ consume rice as breakfast or along with afternoon tea respectively. They consumed green leafy vegetables, bamboo shoots, banana flowers and naturally grown forest vegetables. While analysing non-veg items consumption by the participants, it was found that $38.3 \%$ took twice per week followed by $28.3 \%$ thrice per week, $20.0 \%$ mentioned once a week, $7.5 \%$ alternate days and $5.0 \%$ mentioned whenever available. Nearly thirty three percent consumed milk once a week followed by twice a week (18.3\%) and whenever available (16.7\%), alternate days (5.0\%) and thrice in a week (4.2\%). Nearly $36.7 \%$ consumed eggs twice per week followed by $18.3 \%$ thrice per week and $17.5 \%$ once a week, alternate days $17.5 \%$ and whenever available $5.0 \%$. Almost cent percent consume dry fermented fish. Nearly sixty three percent participants used fermented dry fish while cooking in each vegetable curry preparation. (Table 2). Almost all (98.3\%) consumed Godak (boiled and pasted mixed vegetable items mixed with fermented dry fish \& green chilly) frequently, 28.3\% consumed Godak thrice per week (Table 2), 33.3\% consumed fruit once per week and $40.0 \%$ consumed smoked food. It was also found that $20.0 \%$ consumed smoke food weekly. (Table 3) It was seen that $65.8 \%$ of the participants were daily consumers of edible oil (Table 3) It was interestingly seen that $24.2 \%$ consumed smoked fish followed by vegetable, meat and fish together $(8.3 \%)$, vegetables $(5.8 \%)$, meat only $(1.7 \%)$. (Table 3 ). It was observed that $44.2 \%$ consumed fermented food items. The most commonly used fermented items were bamboo shoots (28.3\%). (Table 3). It was also seen that $34.2 \%$ among the study participants consumed alcoholic beverages. While calculating the BMI it was observed that $9.2 \%$ of the participants' BMI fall $\leq 18.49$, $67.5 \%$ participants' BMI fall within the range of $18.50-24.99$, $20.8 \%$ participants' BMI fall within the range of $25.00-29.99$ and the remaining $2.5 \%$ participants' BMI fall $\geq 30.00$. The mean $( \pm$ SD) value of BMI was $22.481( \pm 3.294)(p=0.000)$. It was further observed that cases of abdominal obesity were $6.52 \%$ and $43.2 \%$ among men and women respectively. It was observed that almost all indigenous population groups consumed dry fermented fish (locally called Shidal). Sixty eight percent of the dry fermented fish consumers' BMI fall within normal range (18.50-24.99) $(\mathrm{p}=0.019)$. Almost seventy four percent $(74.1 \%)$ subjects without abdominal obesity were within normal BMI compared to abdominal obesity (51.4\%) $(\mathrm{p}=0.002)$. Further, nearly seventy-nine $(78.7 \%)$ percent subject who did not consume junk food were within normal BMI compared to junk food eaters $(\mathrm{p}=0.019)$. Consumption of Godak, rice beer and fermented food items could not show association with normal BMI. Interestingly, the physical activities could not show any positive association between exercise and normal BMI range ( $\mathrm{p}=0.667)$. (Table 4).

\begin{tabular}{|c|c|c|c|}
\hline \multirow{4}{*}{ Age (years) } & Variables & $\begin{array}{c}\text { Number } \\
\text { (N) }\end{array}$ & $\begin{array}{c}\text { Percentage } \\
\text { (\%) }\end{array}$ \\
\cline { 2 - 4 } & $\leq 20$ & 13 & 10.8 \\
\cline { 2 - 4 } & $21-30$ & 35 & 29.2 \\
\cline { 2 - 4 } & $31-40$ & 29 & 24.2 \\
\cline { 2 - 4 } & $41-50$ & 25 & 20.8 \\
\cline { 2 - 4 } & $\geq 51$ & 18 & 15.0 \\
\hline \multirow{3}{*}{ Sex } & Male & 46 & 38.3 \\
\cline { 2 - 4 } & Female & 74 & 61.7 \\
\hline
\end{tabular}

\begin{tabular}{|c|c|c|c|}
\hline \multirow{3}{*}{ Literacy } & Illiterate & 16 & 13.3 \\
\hline & Under matric & 52 & 43.3 \\
\hline & Matric and above & 52 & 43.3 \\
\hline \multirow[b]{2}{*}{ Occupation } & Agriculture & 90 & 75.0 \\
\hline & Employed & 30 & 25.0 \\
\hline \multirow{4}{*}{$\begin{array}{c}\text { Income } \\
\text { (Rs.)/month }\end{array}$} & $1000-10000$ & 87 & 72.5 \\
\hline & $10001-20000$ & 23 & 19.2 \\
\hline & $20001-30000$ & 7 & 5.8 \\
\hline & $\geq 30001$ & 3 & 2.5 \\
\hline \multirow{2}{*}{ Family Type } & Nuclear & 102 & 85.0 \\
\hline & Joint & 18 & 15.0 \\
\hline \multirow{3}{*}{$\begin{array}{c}\text { No. of family } \\
\text { members }\end{array}$} & $\leq 3$ & 33 & 27.5 \\
\hline & $4-6$ & 76 & 63.3 \\
\hline & $\geq 7$ & 11 & 9.2 \\
\hline \multirow{2}{*}{ Veg/Non-veg } & Vegetarian & 1 & 0.8 \\
\hline & Non-vegetarian & 119 & 99.2 \\
\hline \multirow{3}{*}{$\begin{array}{c}\text { Physical } \\
\text { activity type }\end{array}$} & Sedentary & 30 & 25 \\
\hline & Moderate & 20 & 16.67 \\
\hline & Heavy & 70 & 58.33 \\
\hline
\end{tabular}

\begin{tabular}{|c|c|c|c|}
\hline Variables & $\begin{array}{l}\text { Items/ } \\
\text { week }\end{array}$ & $\begin{array}{c}\text { Number } \\
(\mathrm{N})\end{array}$ & $\begin{array}{c}\text { Percentages } \\
(\%)\end{array}$ \\
\hline \multirow{4}{*}{ Dry fish } & Daily & 75 & 62.5 \\
\hline & Not always & 17 & 14.2 \\
\hline & Sometimes & 27 & 22.5 \\
\hline & Non-consumer & 1 & 0.8 \\
\hline \multirow{6}{*}{ Godak } & Daily & 10 & 8.3 \\
\hline & Alternate days & 27 & 22.5 \\
\hline & Thrice a week & 34 & 28.3 \\
\hline & Twice a week & 32 & 26.7 \\
\hline & Once a week & 15 & 12.5 \\
\hline & Non-consumer & 2 & 1.7 \\
\hline \multirow{6}{*}{ Smoked food } & $\begin{array}{c}\text { Whenever } \\
\text { available }\end{array}$ & 1 & 0.8 \\
\hline & Alternate days & 1 & 0.8 \\
\hline & Thrice a week & 5 & 4.2 \\
\hline & Twice a week & 17 & 14.2 \\
\hline & Once a week & 24 & 20.0 \\
\hline & Non-consumer & 72 & 60.0 \\
\hline \multirow{5}{*}{ Edible Oil } & Alternate days & 12 & 10.0 \\
\hline & Thrice a week & 9 & 7.5 \\
\hline & Twice a week & 11 & 9.2 \\
\hline & Once a week & 9 & 7.5 \\
\hline & Daily & 79 & 65.8 \\
\hline
\end{tabular}

\begin{tabular}{|c|c|c|c|}
\hline Variables & Items & $\begin{array}{c}\text { Number } \\
\text { (N) }\end{array}$ & $\begin{array}{c}\text { Percentages } \\
\text { (\%) }\end{array}$ \\
\hline \multirow{4}{*}{$\begin{array}{c}\text { Smoked food } \\
\text { type }\end{array}$} & Vegetable & 7 & 5.8 \\
\cline { 2 - 4 } & Meat & 2 & 1.7 \\
\cline { 2 - 4 } & Fish & 29 & 24.2 \\
\cline { 2 - 4 } & All of the above & 10 & 8.3 \\
\hline \multirow{4}{*}{$\begin{array}{c}\text { Fermented } \\
\text { foods }\end{array}$} & Bamboo shoots & 34 & 60.0 \\
\cline { 2 - 4 } & Fish fermented & 5 & 28.3 \\
\cline { 2 - 4 } & $\begin{array}{c}\text { Both bamboo shoots } \\
\text { and fish }\end{array}$ & 14 & 11.7 \\
\cline { 2 - 4 } & Non-consumer & 67 & 55.8 \\
\hline Table 3. Types of smoked Food and Fermented Items \\
Consumption by the Participants \\
\hline \multicolumn{4}{|c|}{} \\
\hline \multirow{4}{*}{}
\end{tabular}




\begin{tabular}{|c|c|c|c|c|c|c|}
\hline \multirow{2}{*}{\multicolumn{2}{|c|}{ Variables }} & \multicolumn{4}{|c|}{ BMI } & \multirow[b]{2}{*}{ P value } \\
\hline & & \multirow{2}{*}{$\begin{array}{c}<18.50 \\
\mathrm{~N}(\%) \\
10(8.4)\end{array}$} & \multirow{2}{*}{$\begin{array}{c}18.50-24.99 \\
N(\%) \\
81(68.1)\end{array}$} & \multirow{2}{*}{$\begin{array}{c}25.00-29.99 \\
N(\%) \\
25(21.0)\end{array}$} & \multirow{2}{*}{$\begin{array}{c}\geq 30.00 \\
N(\%) \\
3(2.5)\end{array}$} & \\
\hline Dru formontod fich & Yes & & & & & \multirow[b]{2}{*}{0.019} \\
\hline Dry fermented fish & No & $1(100.0)$ & $0(0.0)$ & $0(0.0)$ & $0(0.0)$ & \\
\hline \multirow{2}{*}{ Godak } & Yes & $10(8.5)$ & $80(67.8)$ & $25(21.2)$ & $3(2.5)$ & \multirow[b]{2}{*}{0.234} \\
\hline & No & $1(50.0)$ & $1(50.0)$ & $0(0.0)$ & $0(0.0)$ & \\
\hline \multirow{2}{*}{ Abdominal obesity } & Yes & $1(2.9)$ & $18(51.4)$ & $14(40.0)$ & $2(5.7)$ & \multirow[b]{2}{*}{0.002} \\
\hline & No & $10(11.8)$ & $63(74.1)$ & $11(12.9)$ & $1(1.2)$ & \\
\hline \multirow{2}{*}{ Rice beer } & Yes & $3(7.3)$ & $26(63.4)$ & $10(24.4)$ & $2(4.9)$ & \multirow[b]{2}{*}{0.537} \\
\hline & No & $8(10.1)$ & $55(69.6)$ & $15(19.0)$ & $1(1.3)$ & \\
\hline \multirow[b]{2}{*}{ Physical activity } & Sedentary & $3(10.0)$ & $22(73.3)$ & $5(16.7)$ & $0(0.0)$ & \multirow[b]{2}{*}{0.667} \\
\hline & Moderate/Heavy & $8(8.9)$ & $59(65.6)$ & $20(22.2)$ & $3(3.3)$ & \\
\hline \multirow{2}{*}{ Junk food } & Yes & $5(8.5)$ & $33(55.9)$ & $19(32.2)$ & $2(3.4)$ & \multirow[b]{2}{*}{0.019} \\
\hline & No & $6(9.8)$ & $48(78.7)$ & $6(9.8)$ & $1(1.6)$ & \\
\hline \multirow{2}{*}{ Fermented items } & Yes & $4(7.5)$ & $38(71.7)$ & $9(17.0)$ & $2(3.8)$ & \multirow{2}{*}{0.590} \\
\hline & No & $7(10.6)$ & $42(63.6)$ & $16(24.2)$ & $1(1.5)$ & \\
\hline
\end{tabular}

\section{DISCUSSION}

This study was conducted to know the food consumption pattern and nutritional status among indigenous population group of Tripura. As expected majority among them have common food consumption habits like use of Godak curry and fermented food items. This Godak curry was a very special dish and tasty menu among the indigenous population of Tripura. The vegetables like bamboo shoot, banana stem and banana flower were frequently used items. Bamboo shoots were one important component in making Godak. Bamboo shoots were a popular food item in North-East region and form a major part of traditional cuisine. Earlier it was also a solution for food security in the dense forest and remote areas during lean period.10, 11, 12 According to species or variety of bamboo, the shoots were consumed fresh, dried or fermented. Like people from Mizoram state prefer fresh slender and soft shoots of Melocanna baccifera and Phyllostachys mannii. Khasi, Garo and Jaintia tribes of Meghalaya prefer big, slightly harder shoots of Dendrocalamus hamiltonii, but after fermentation. The Meetei people of Manipur prefer fresh shoots of Bambusa nutans for preparing Ooti and Kangsu and fermented shoots for making of Soibum and Soijin-eronba. Similarly, they also prefer apical shoots of Chimonobambusa callosa as fresh for making various food items. ${ }^{12}$ In Tripura the commonly consumed bamboo species were Bambusa pallida, B. tulda, B. polymorpha, Dendrocalamus hamiltonii, D. longispathus, Gigantochloa rostrata, Melocanna baccifera (locally Warthoi/Mauli bamboo).12 Bamboo shoots contain 2.65\% protein on average. The Bamboo protein contains 8 essential and 2 semi-essential amino acids, fibre, selenium, a potent anti-oxidant and potassium; healthy heart minerals. ${ }^{13}$ Some people prepare pickles from the fresh shoots of these species of bamboo. Usoi-Ooti of Manipur, Rawtui-bai of Mizoram, Moiya-godak of Tripura were some of the important recipes prepared from fresh shoots of bamboo.12 Use of oil while cooking, consumption of tea and snacks were observed among the study population groups. It might be due to gradual learning of common habits and cultural exchange between different population groups in the state. It is noteworthy to mention that oils, snacks and tea, etc. consumption habits were not common among these groups of population in older times. But in the present study, we observed that infrequently oil was used in many food preparations. Meat, egg and fish consumption were as usual comparable with other nonindigenous group of population. A report made by some authors that among tribal households, there were deficiencies in the intake of pulses and legumes, milk and milk products, fats and oils, and sugar and jaggery. Anthropometric indices also show high levels of malnutrition. ${ }^{3}$ In our study, BMI revealed that nutritional status was within normal range in majority of the cases. Few of the participants were malnourished according to our findings. Very few of the participants were either thin or overweight and obese. It was not comparable to the study conducted by Deka $S$ et al. ${ }^{3}$ But no strong evidence could be made to support our findings due to localised and limited to small study area of the state. It cannot be generalised to whole population of the state. Hence, we recommend a larger study. It was also found that smoked food products and fermented items were consumed by the indigenous tribal population. But it was prepared in less extent nowadays because of non-availability and high cost of fish. The similar types of items consumption were reported from Manipur by some authors.9, 12 Further, consumption of alcoholic beverage was observed among this population group. It is to mention that in the past offering of alcohol beverages to the guest was common as a traditional social custom among some of the indigenous population groups. Now, it has been gradually replaced by tea and snacks, etc. that might be due to changes in socioeconomic status and education. The similar report was made by some authors from Tripura. $^{9}$ In case of abdominal obesity, females were higher in number compared to males. This might be due to nature of work or exercise performed by individuals in addition to their dietary habits. The males had more physical activities in the field compared to females especially in rural areas. Sixty eight percent of the dry fermented fish consumers' BMI was within normal range $(p=0.019)$. The fat or oil content of dry fish is very minimal but there is more protein content compared to fresh fish. The indigenous population group as such very infrequently consume oil as daily need but more commonly prefer dry fermented fish. Protein content in fish is $16-20 \%$ of the total weight. According to the regulations, protein content in fresh haddock is about $17-19 \%$ but in dried haddock the protein content is about $75-80 \% .{ }^{14}$ Further, the fat content is $0.6 \%$ 
to $0.8 \%$ in dried fish. ${ }^{14}$ Almost seventy four percent $(74.1 \%)$ subjects without abdominal obesity were within normal BMI compared to abdominal obesity ( $\mathrm{p}=0.002$ ).

It is widely known that physical activities in moderate to heavy form reduce body weight, reduce body fats, etc and help in keeping normal body weight leading to normal BMI but interestingly, our present study could not show any positive association of exercise and normal BMI range $(\mathrm{p}=0.667)$. (Table 4) Small sample size might be a factor for this condition. Hence, we recommend larger study.

\section{CONCLUSION}

The commonly consumed fat-free diet and nature of their physical activities might help in keeping the body weight within normal range. The few fat-free special items like Godak curry including naturally grown forest vegetables preferred by them might be helpful in keeping them healthy. This study result may be useful for health administrator, planners in the state. In this regard, we suggest further studies including more subjects and covering wider areas of the state. We cannot generalise the present study findings but they may be of great help for the future researchers.

Strength and Limitation: The BMI in relation to food habit was not frequently studied in this population group. The food habits of Indigenous population were peculiar compared to other population group in the state. Forest vegetable products which contain abundant fibres (also rich in vitamins and minerals) were preferred by this population group which might help in maintaining normal BMI for most of the individuals. This study cannot be generalised due to small sample size and limited to small population group.

\section{Recommendations}

We recommend further study with larger sample size including proportional representation from different indigenous population groups covering all districts of the state.

\section{ACKNOWLEDGMENT}

We acknowledge all participants without whom this would not have been possible to bring into reality.

\section{REFERENCES}

[1] Nagda BL. Tribal population and health in Rajasthan. Studies of Tribes and Tribals 2004;2(1):1-8.

[2] Mondal P. Essay on tribes in India (researched essay). www.yourarticlelibrary.com/tribes/essay-on-tribes-inindia-researched-essay/4416/ (Accessed on 10/06/2016).
[3] Deka S. Health and nutritional status of the Indian tribes of tripura and effects on education. Student PulseThe International Student Journal 2011;3(3):1/1.

[4] Culture of Tripura. Available at https://en.m.wikipedia.org/wiki/Culture_of_Tripura (Accessed on 10/07/2016).

[5] Tripura human development report: a summary. Available at: http://tripura.nic.in/hdr/tripura\%20hdrsummary.pdf (Accessed on 12/07/2016).

[6] Gopalan C, Rao KJ. The problem of malnutrition. In: Falkner F, (eds). Prevention in childhood of health problems in adult life. Geneva, Switzerland: World Health Organization, 1980.

[7] ICMR. Nutrient requirement and recommended dietary allowances for Indians, a report of the expert group of the ICMR, 2010. Available at: icmr.nic.in/final/rda2010.pdf (Accessed on 14/07/2016).

[8] Dietary reference intakes: a risk assessment model for establishing upper intake levels for nutrients. Institute of Medicine (US) Food and Nutrition Board Washington (DC): National Academies Press (US); $1998 . \quad$ Available at http://www.ncbi.nlm.nih.gov/books/NBK45182/ (Accessed on 12/07/2016).

[9] Uchoi D, Roy D, Majumdar RK, et al. Diversified traditional cured food products of certain indigenous tribes of Tripura, Indian. Indian Journal of Traditional Knowledge 2015;14(3):440-6.

[10] Bhatt BP, Singha LB, Singh K, et al. Some commercial edible bamboo species of north east India: production, indigenous uses, cost-benefit and management strategies. J Am Bamboo Soc 2003;17(1):4-20.

[11] Tamang B, Tamang JP. Traditional knowledge of biopreservation of perishable vegetables and bamboo shoots in Northeast India as food resources. Indian Journal of Traditional Knowledge 2009;8(1):89-95.

[12] Bisht MS, Nirmala C, Meetei OS. Bamboo shoots for food in North-East India: conventional and contemporary. In: Proceedings of 10th world bamboo congress, theme: food and pharmaceuticals. 2015. Damyang, Korea. http://www.worldbamboo.net/proceedings/wbcx.

[13] Singhal P, Bal LM, Satya S, et al. Bamboo shoots: a novel source of nutrition and medicine. Crit Rev Food Sci Nutr 2013;53(5):517-34.

[14] Ásbjörn J, Guðrún AF, Guðjón P, et al. Dried fish as health food. Matísohf/Matis-Food Research, Innovation \& Safety 2007:1-21. 